\title{
ПРАВОВОЕ РЕГУЛИРОВАНИЕ ИМУЩЕСТВЕННЫХ ОТНОШЕНИЙ РОДИТЕЛЕЙ И ДЕТЕЙ В РОССИЙСКОЙ ИМПЕРИИ В НАЧАЛЕ ХХ ВЕКА
}

Одной из наиболее дискутируемых проблем в отечественной цивилистике является социально-правовой статус ребенка в Российской империи в начале XX века. Российское гражданское и семейное законодательства не лишены недостатков, пробелов и противоречий, что относится и к теме данного исследования. Сказанное побудило авторов обратиться к анализу узких вопросов обозначенной проблемы - правовому регулированию имущественных отношений в семье родителей и детей.

Актуальность темы исследования предопределена огромным научным и практическим потенциалом вопросов наследования имущества. Интерес к данной правовой проблеме относится не только к истории отечественной цивилистики, но и к обозначению вектора развития законодательства в XXI веке.

Национальное право Российской империи, опираясь на вековые традиции, менталитет граждан и сложившуюся к началу XX века практику, сделало реальную попытку закрепления имущественных отношений в семье родителей и детей в нормативно-правовых актах и статьях законов.

Авторы статьи обращают внимание на непростую правоприменительную практику реализации контроля за фактическим исполнением действующего законодательства. Это можно объяснить спецификой традиций быта россиян, закрытостью семейно-родственных от-

ношений, которые можно отнести в разной степени ко всем сословиям общества.

По убеждению авторов, определяющую роль в регулировании имущественных отношений в семье играло ненормативное традиционное право, закрепленное не в позитивных законах российского государства, а в существующих веками обычаях с учетом национальных, конфессиональных и социальных особенностей.

Новизна данной работы заключается в попытке введения в научный оборот новых правовых конструкций в разные отрасли современного российского права.

Принципиальным является вывод авторов статьи о том, что имущественные отношения в современной семье российских граждан должны более активно регулироваться государством. Повышение роли государственной власти и контроль за исполнением конкретизированных нормативно-правовых актов будут способствовать оздоровлению семейно-родственных отношений и укреплению семьи россиян как основы современного общества в сложных условиях политической и экономической нестабильности формировании я новой государственности России.

Ключевые слова: семья, родители, дети, семейное право, наследственное право, имущественные отношения, права собственности.

\section{E. Atarshchikova, E. Ponomarev}

\section{LEGAL REGULATION OF PROPERTY RELATIONS BETWEEN PARENTS AND CHILDREN IN THE RUSSIAN EMPIRE IN THE EARLY TWENTIETH CENTURY}

One of the most debated problems in the domestic civil law is the social and legal status of the child in the Russian Empire in the early twentieth century. Russian civil and family legislation is not without flaws, gaps and contradictions, which concerns the topic of this study. This prompted the authors to turn to the analysis of the minor issues of the problem - the legal regulation of parents-children property relations.

The relevance of the research topic is predetermined by the huge scientific and practical potential of inheritance of property. The interest in this legal problem relates not only to the history of Russian civil law, but also to the designation of the vector of development of legislation in the XXI century.

The national law of the Russian Empire, based on centuries-old traditions, mentality of citizens and the practice developed by the beginning of the twentieth century, made a real attempt to consolidate property relations in the family of parents and children in normative legal acts and articles of laws.
The authors of the article pay attention to the difficult law enforcement practice of control over the actual implementation of the current legislation. This can be explained by the specifics of life traditions of Russians, the closeness of family-related relations, which can be attributed to varying degrees to all classes of society.

According to the authors, the determining role in the regulation of property relations in the family played a non-normative traditional law, enshrined not in the positive laws of the Russian state, but in the customs existing for centuries, taking into account national, confessional and social characteristics.

The novelty of this work is an attempt to introduce new legal structures into scientific circulation in different branches of modern Russian law.

The main conclusion of the authors of the article is that property relations in the modern family of Russian citizens should be more actively regulated by the state. Increasing the role of state power and control over the implementation of specific legal acts will contribute to the improvement of 
family relations and strengthen the family of Russians as the basis of modern society in difficult conditions of political and economic instability, the formation of a new state of Russia.

Социально-правовой статус ребенка в России является одной из наименее изученных проблем в отечественной цивилистике. На наш взгляд, это относится ко всем периодам развития нашего государства.

Интерес к данной правовой проблеме относится не только к истории отечественной цивилистики, но и к обозначению вектора развития законодательства в XXI веке

Национальное право Российской империи, опираясь на вековые традиции, менталитет граждан и сложившуюся к началу XX В. практику, сделало реальную попытку закрепления имущественных отношений в семье родителей и детей в нормативно-правовых актах и статьях законов.

Попробуем рассмотреть некоторые аспекты этой темы в наиболее активный, если не сказать трагический, период нашей истории - начало XX в. Страна испытывала острую необходимость перемен во всех сферах политического, экономического, социального развития.

Положение детей и отношение государства к регулированию их статуса посредством правовых и нравственных рычагов - достаточно локальная сфера государственного воздействия на любом этапе исторического развития. В то же время от успеха ее решения, в конечном итоге, зависит судьба государства, общества и страны в целом.

В данной статье нас интересует более узкий вопрос обозначенной проблемы - правовое регулирование имущественных отношений в семье родителей и детей

Отметим, что, по нашему убеждению, автономность родительской авторитарность в семье периода начала XX в., закрепленная законом и общественными традициями в сфере личных отношений, не могла не сказаться на имущественных правах родителей и детей.

По утверждению известного дореволюционного отечественного правоведа Синайского В. И., в общеимперском законодательстве устанавливалась раздельность имущества родителей и детей.

Имущественная часть родителей не могла претендовать на частную собственность их детей. В данном случае они могли распоряжаться имуществом детей только с их согласия [10].

Эта имущественная обособленность реализовалась посредством выдела.

Под отпущением имущества отечественные юристы имели в виду дар, который осуществлялся родителями в пользу детей, их законных наследников. Этот правовой акт совершался «с целью передать наследственную часть до смерти наследодателя» [16, с.337].

По действующим нормам все права собственности переходили к новому владельцу, и родители уже не имели возможности контролировать
Key words: family, parents, children, family law, inheritance law, property relations, property rights.

ставшее «детским» имущество [2, с. 28-32] Российское законодательство приданое также определяло как часть имущества, подлежащего выделению дочерям от общего брака или родственницам [6].

В связи с этим действовавшим законом было установлено понятие «неотделенного ребенка» как лица, которому такая «законная доля) выделена не была. Это положение выделялось в отдельную юрисдикцию, по которой неотделенные дети не имели право на имущество родителей, а родители не отвечали за их долговые обязательства [12].

Имущественные отношения полностью по действующему законодательству определялись родителями. Дети, даже по достижении их совершеннолетия, не имели права требовать имущественного выдела [13].

Объем выделяемого имущества также не был ограничен. В случае получения выдела за ребенком влекло за собой лишение права на оставшееся имущество, приобретенное родителями в результате последующей предпринимательской деятельности. Наследник мог рассчитывать исключительно на определенную законом долю родового имущества, если он не получил ее при выделе.

Однако в действующей правовой доктрине разделение детей на отделенных и неотделенных оценивалось лишь как формальная дань традиции существовавшей ранее общности семейной собственности. На самом деле это было не ущемление прав как тех, так и других. Неотделенные дети были самостоятельны в имущественных отношениях, как и отделенные. В данном случае имела место быть мера дееспособности детей т.е. возрастное наступление их совершеннолетия $[1$, c. 321$]$.

C позиций современной юриспруденции мы можем констатировать, что неотделенные дети имели практически такие же имущественные права, как и отделенные.

Имущественные права родителей в отношении тех и других также ограничивались только управлением в порядке опекунства [8]

Достаточно спорные взгляды в правовой науке России начала XX века имел вопрос законодательной регламентации обязанности родителей по содержанию детей.

Законом на родителей возлагался одинаковый объем обязанностей по содержанию, как отделенных, так и неотделенных детей.

Так, статьей 172 Законов гражданских было установлено, что родители обязаны были обеспечить несовершеннолетних детей пропитанием, одеждой и воспитанием на принципах добра и чести [7] 
Большинство цивилистов, отмечая результаты законотворчества, положительно оценивали эти тенденции развития права, одобряли усиление правовой защищенности детей. Действительно не собрание семьи, которое может быть субъективно, а государство защищало интересы детей, государственное регулирование брало на себя обязательство контроля за злоупотреблением внутрисемейных отношений.

Проблема материального обеспечения на содержание детей и их воспитание тесно связана с беспризорностью несовершеннолетних и уровнем детской преступности.

По мнению дореволюционного правоведа Люблинского П. И., проблема детской беспризорности и попрошайничества не могла быть решена без введения особых законодательных санкций для родителей, уклонявшихся от выполнения своих обязанностей по содержанию детей [3, с. 12].

В этом смысле укоренившаяся в общественном сознании уверенность родителей в безнаказанности за неисполнение своих обязательств по отношению к детям являлась одним из препятствий в решении назревшей проблемы.

В качестве ужесточения ответственности родителей предлагалось предоставить по решению мирового судьи право изымать «беспризорных» детей из семьи и поручать их содержание и воспитание в благополучную семью с благонадежной репутацией. В то же время на родителей налагалась определенная обязанность в форме их денежного содержания в приемной семье. Если суд считал возможным оставить ребенка при ненадлежащем содержании и воспитании они могут быть подвержены тюремному заключению. В случае умышленного лишения детей пищи, крова, одеяния и пр., а также недобросовестного исполнения своих родительских обязанностей, повлекших за собой негативные последствия для ребенка, они могут быть подвержены денежным штрафам. В этом случае учитывалось материальное положение родителей, в действиях которых не проявлялся злой умысел [4, с. 50-52].

Однако жизнь показывала, что ни одна из предложенных мер не была реализована на практике в полной мере. Проблема источника денежного содержания детей, а также контроля за их расходованием со стороны родителей, считались по-прежнему делом семьи, и эти вопросы не входили в компетенцию государственного контроля.

Более того, родителям принадлежала вся полнота прав на результаты детского труда. В этой сфере законодательство также ограничивалось декларативными нормами, прямо не предусматривая запрет на злоупотребление эксплуатации рабочей силы несовершеннолетних.

Нормативно-правовые акты касались только одной обязательной нормы, а именно - согласия родителей на работу своего несовершеннолетнего ребенка. Однако это обязательное условие легко преодолевалось положением законодательного права определять своих малолетних детей «в ученье» на любой срок [11]. Учитывая пол- ную зависимость детей от отца и матери, а также бесконтрольность со стороны родительской власти, им легко было добиться согласие ребенка на наемную работу

Содержание детей своими родителями в обязательном порядке апеллируют алиментарные обязательства детей по отношению к родителям.

Законодательство Российской империи, в отличие от западноевропейского, признавало право содержание родителей их детьми, то есть получать от них алименты. Но это не распространялось на других родственников. Полноценного алиментарного института в дореволюционной России не сложилось, в связи с чем, например, дед или бабка не могли требовать содержания от своих внуков или внучек.

Согласно ст. 194 Законов гражданских, дети обязаны были доставлять пропитание и содержание родителям, находящимся в «бедности, дряхлости или немощи», в течение всей их жизни, причем независимо от их отделенности от родителей $[14$, с. 293]. В случае недобросовестного выполнения этих имущественных и финансовых обязательств по Уставу мировых судей дети могли быть подвергнуты аресту сроком до трех месяцев [15].

Регулирование имущественной ответственности родителей традиционно разделялось на ответственность по обязательствам детей и ответственность за вред и убытки, причиненные их неправомерными действиями (деликт).

Как отмечалось выше, статьей 184 Законов гражданских было установлено, что родители не отвечают по обязательствам неотделенных детей («заёмным письмам и вообще всяким долговым актам»), выданных без их согласия [9].

В наше время интересно подчеркнуть, что общественное мнение начала XX века было на стороне детей, а не родителей. В качестве аргументов мы можем предположить, что окружающее сообщество вменяло родителям в вину недостойное воспитание своих детей, которые безрассудно могли взять деньги взаем без возможности их вовремя отдать. Следовательно, по этой логике родители должны отвечать по обязательствам своих совершеннолетних воспитанников. В дополнение к этому, за детьми оставалось право опубликовать причины консрликта с родителями.

Важно подчеркнуть, что в противовес предыдущему положению, материально-финансовая ответственность родителей за ущерб, причиненный несовершеннолетними детьми, возмещалась только в том случае, если признавался факт недобросовестного отношения родителей к своему долгу по воспитанию детей. $У$ родителей оставалось право оспорить в судебном порядке факт своей непричастности к нанесенному их ребенком материального вреда и отсутствия у них возможности предотвратить содеянное. В этом случае ответственность распространялась на отдельное имущество несовершеннолетнего [5].

Обращаем внимание на непростую правоприменительную практику реализации контроля за 
фактическим исполнением действующего законодательства. Это можно, с нашей точки зрения, объяснить спецификой традиций быта россиян, закрытостью семейно-родственных отношений, которые можно отнести в разной степени ко всем сословиям общества.

По нашему убеждению, определяющую роль в регулировании имущественных отношений в семье играло ненормативное традиционное право, закрепленное не в позитивных законах российского государства, а в существующих веками обычаях с учетом национальных, конфессиональных и социальных особенностей

Итак, в сорере имущественных отношений с родителями российский закон наделял несовершеннолетних весьма широкой самостоятельностью, выражавшейся в установлении раздельности имущества родителей и детей. Однако эти нормы зачастую носили формальный и декларативный характер. На практике, ввиду отсутствия государственного контроля, решение всех вопросов распоряжения и пользования имуществом зависело исключительно от воли родителей. Требование закона об обязанности родителей содержать детей, будучи неподкрепленным какими-либо санкциями, на деле также являлось в значительной степени моральным, чем правовым.

Повышение роли государственной власти и контроль за исполнением конкретизированных нормативно-правовых актов будут способствовать оздоровлению семейно-родственных отношений и укреплению семьи россиян как основы современного общества в сложных условиях политической и экономической нестабильности формирования новой государственности России.

Подводя итоги отечественному историческому опыту и пытаясь проецировать его на современную российскую действительность, мы можем сделать вывод о том, что имущественные отношения в семье граждан РФ должны более активно регулироваться государством

Этот исторический опыт может быть полезен для осмысления и определения вектора развития права и в современной России

\section{Литература}

1. Заговорский А. И. Курс Семейного права. Одесса: [б.и.], 1909. 554 с

2. Любавский Л. П. Выдел имущества // Юридические монографии и исследования. Т. 4. М.: [б.и.], 1986. 205 с

3. Люблинский П. И. Новые идеи в правоведении // Цели наказания. №1. СПб.: Образование, 1914. С. 1

4. Люблинский П. И. Ответственность за оставление семьи без средств // Журнал министерства юстиции. сПб. Сенат, 1915. №3. С. 1-37.

5. Свод законов (Св. Зак.) Т. Х Ч. 1. Законы гражданские. Изд. 1914 г. Ст. 653-654, 636.

6. Св. Зак. Т. Х. Ч. 1. Законы гражданские. Ст. 1001

7. Св. Зак. Т. Х. Ч. 1. Законы гражданские. Ст. 172

8. Св. Зак. Т. Х. Ч. 1. Законы гражданские. Ст. 180

9. Св. Зак. Т. Х. Ч. 1. Законы гражданские. Ст. 184-188.

10. Св. Зак. Т. Х. Ч. 1. Законы гражданские. Ст. 193.

11. Св. Зак. Т. Х. Ч. 1. Законы гражданские. СТ. 2203

12. Св. Зак. Т. Х. Ч. І. Законы гражданские. Ст. 182-190.

13. Св. Зак. Т. Х. Ч. І. Законы гражданские. Ст. 995.

14. Синайский В. И. Русское гражданское право. Вып. 2. Киев: Прогресс, 1915. 567 с

15. Устав о наказаниях, налагаемых мировыми судьями. СПб: [б.и.], 1914. Ст. 143

16. Шешеневич Г. Ф. Учебник русского гражданского права. Т.І. СПб: [б.и.], 1915. 461 с.

\section{References}

1. Zagovorskij A. I. Kurs Semejnogo prava (Course on Family law). Odessa, 1909. 554 p. (In Russian).

2. Ljubavskij L. P. Vydel imushhestva (Property allocation) // Juridicheskie monografii i issledovanija. T.4. Moscow: [b.i.], 1986. 205 p. (In Russian)

3. Ljublinskij P. I. Novye idei v pravovedenii (New ideas in law) // Celi nakazanija. No.1. St.Petersburg: Obrazovanie, 1914. P. 1. (In Russian).

4. Ljublinskij P. I. Otvetstvennost' za ostavlenie sem'i bez sredstv // Zhurnal ministerstva justicii. St.Petersburg: Senat 1915. No. 3. P. 1-37. (In Russian).

5. Svod zakonov (Code of laws). Vol. X Part. 1. Zakony grazhdanskiev (Civil laws). 1914. Art. 653-654, 636. (In Russian)

6. Svod zakonov (Code of laws). Vol. X Part. 1. Zakony grazhdanskiev (Civil laws). 1914. Art. 1001. (In Russian).

7. Svod zakonov (Code of laws). Vol. X Part. 1. Zakony grazhdanskiev (Civil laws). 1914. Art. 172. (In Russian).

8. Svod zakonov (Code of laws). Vol. X Part. 1. Zakony grazhdanskiev (Civil laws). 1914. Art. 180. (In Russian)

9. Svod zakonov (Code of laws). Vol. X Part. 1. Zakony grazhdanskiev(Civil laws). 1914. Art.184-188. (In Russian).

10. Svod zakonov (Code of laws), Vol. X Part. 1. Zakony grazhdanskiev (Civil laws). 1914. Art. 193. (In Russian).

11. Svod zakonov (Code of laws). Vol. X Part. 1. Zakony grazhdanskiev (Civil laws). 1914. Art. 2203. (In Russian).

12. Svod zakonov (Code of laws). Vol. X Part. 1. Zakony grazhdanskiev (Civil laws). 1914. Art. 182-190. (In Russian).

13. Svod zakonov (Code of laws). Vol. X Part. 1. Zakony grazhdanskiev (Civil laws). 1914. Art. 995. (In Russian).

14. Sinajskij V. I. Russkoe grazhdanskoe pravo (Russian civil law). Issue. 2. Kiev: Progress publ., 1915. 567 p. (In Russian).

15. Ustav o nakazanijah, nalagaemyh mirovymi sud'jami (Statute of penalties imposed by justice judges). St.Petersburg 1914. Art. 143. (In Russian).

16. Sheshenevich G. F. Uchebnik russkogo grazhdanskogo prava (Textbook of Russian civil law). Vol. I. St.Petersburg 1915. 461 p. (In Russian) 


\section{Сведения об авторах}

Атарщикова Елена Николаевна - доктор юридических наук, профессор кафедры правовой культуры и защиты прав человека юридического института Северо-Кавказского федерального университета (Ставрополь) / PonomarevE@yandex.ru

Пономарев Евгений Георгиевич - доктор юридических наук, профессор (Ставрополь) / PonomarevE@yandex.ru

\section{Information about the authors}

Atarshchikova Elena - Dr. of Legal Science, Professor, Chair of Law Culture and Protection of Human Rights, Institute of Law, North Caucasus Federal University (Stavropol) / anisimovap@mail.ru

Ponomarev Evgenii - Dr. of Legal Science, Professor (Stavropol) / PonomarevE@yandex.ru 